\title{
A PROPÓSITO DE DOS NUEVOS AMULETOS DE BES PROCEDENTES DE CHIPIONA Y ROTA (CÁDIZ)
}

\author{
SOME REFLECTIONS ABOUT TWO NEW AMULETS OF \\ BES FROM CHIPIONA AND ROTA (CÁDIZ)
}

\author{
ÁLVARO GÓMEZ PEÑA* \\ JESÚS RODRÍGUEZ MELLADO**
}

\begin{abstract}
Resumen: En este trabajo se dan a conocer dos nuevos amuletos de Bes procedentes de las inmediaciones del santuario de Nuestra Señora de Regla en Chipiona y del yacimiento de Viña de las Cántaras en Rota, ambos en la provincia de Cádiz. A propósito de su publicación se propone una explicación biologicista para el uso profiláctico de esta figura contra el mal de ojo y se hace énfasis en la creencia y utilización de Bes como deidad también durante los períodos republicano e imperial romanos.
\end{abstract}

Palabras Clave: Bes, tumbas púnicas, villa romana, alfar.

\section{INTRODUCCIÓN}

La imagen de Bes gozó de éxito y buena acogida entre los pueblos del Mediterráneo en la Antigüedad debido a sus atributos y cualidades profilácticas. Su singular imagen fue parte importante en este hecho ya que por lo general los dioses mediterráneos no presentan en su iconografía como características físicas un acusado enanismo, una mueca temible o un orondo perfil. Entre los arqueólogos su fama es tal que a veces se

\footnotetext{
* Becario predoctoral PIF de Necesidades Docentes, Departamento de Prehistoria y Arqueología. Universidad de Sevilla. María de Padilla s/n. 41004. Sevilla. Grupo de Investigación TELLUS.
}

\begin{abstract}
In this article we publish two new amulets of Bes found near the sanctuary of Our Lady of Regla in Chipiona and in the archaeological site of Viña de las Cántaras at Rota, both of them in the province of Cadiz. About its publication we propose a biologicist explanation for the profilactic use of this figure against the evil eye and we emphasize the belief and use of Bes as a deity during both the Republican and Imperial Roman periods.
\end{abstract}

Key words: Bes, Punic Tombs, Roman Villae, Pottery Workshop.

han confundido con su singular figura amuletos de silenos o patecos, entre otros. Del mismo modo, los clichés que sobre su personalidad y atribuciones se han venido publicando suelen dejar a un lado otra serie de características propias de su culto que, por mostrarse como singularidades en el registro arqueológico o por ser temática o cronológicamente lejanas a su autor, han pasado generalmente desapercibidas. Sin embargo, a pesar de ser tan conocidos, los ejemplares atribuidos a

Prehistoria y Arqueología en el Sur de Iberia (HUM-949). Correoe: agomez19@us.es

** Arqueólogo profesional. Avda. de Madrid, 61, Bajo D. 11550. Chipiona (Cádiz). Grupo de Investigación De la Turdetania a la Bética (HUM-152). Correo-e: jesusrodriguezmellado@hotmail.com 


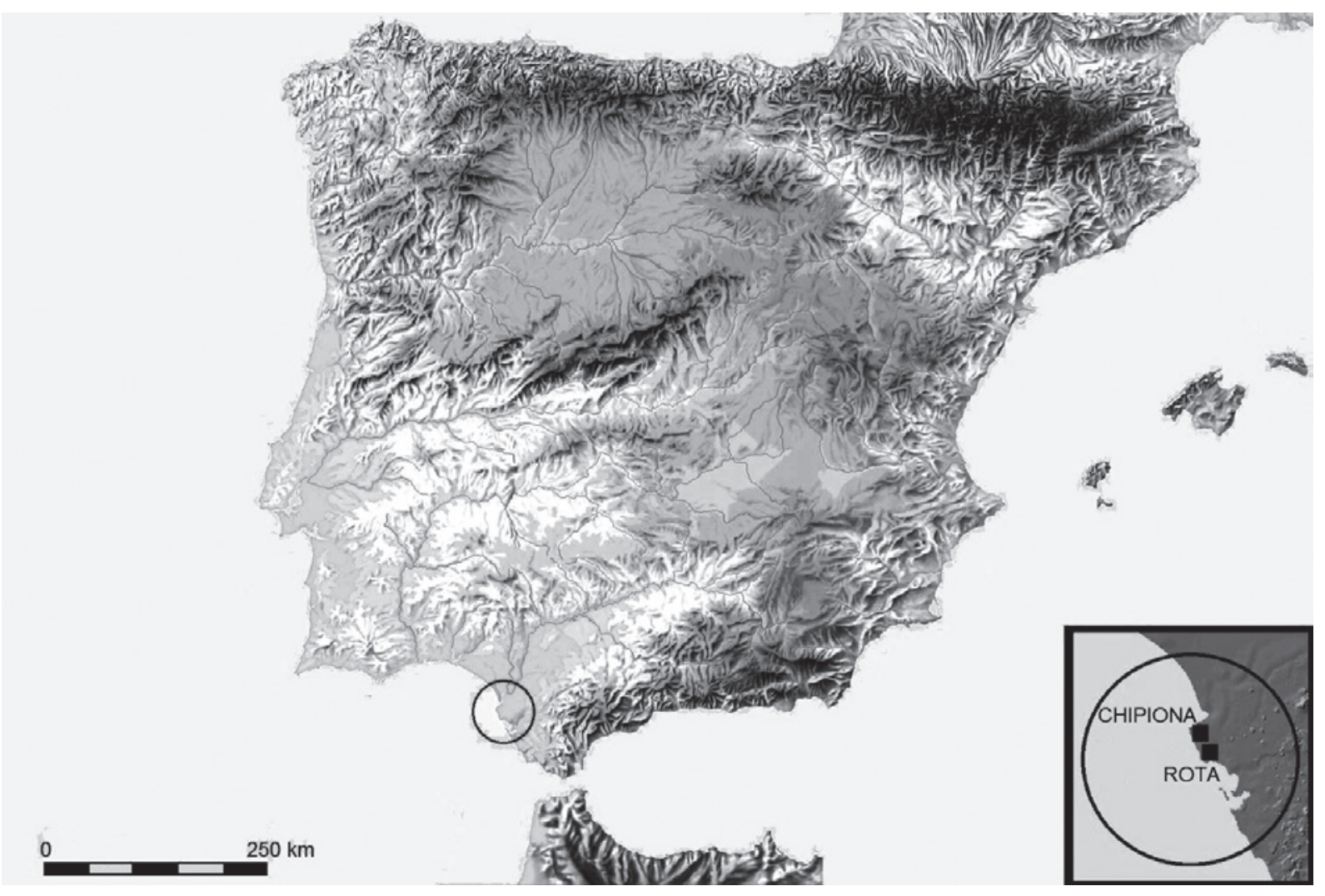

Figura 1. Mapa con la localización de los municipios de los que proceden los amuletos.

Bes en la península ibérica, incluyendo amuletos, escarabeos y terracotas sobrepasan difícilmente la veintena, como tratamos más adelante. La publicación de los dos nuevos amuletos que presentamos en este trabajo procedentes de las localidades gaditanas de Chipiona y Rota (fig. 1) apunta la posibilidad de una continuidad de su culto en el ámbito de la Bahía de Cádiz durante la época romana, aspecto este que por lo general ha sido escasamente considerado entre la bibliografía al uso (Gómez 2002, Velázquez 2007).

\section{BES PROCEDENTE DE LAS \\ INMEDIACIONES DEL SANTUARIO DE NUESTRA SEÑORA DE REGLA}

El primero de los amuletos, fabricado en arcilla, presenta unas dimensiones de $3,5 \mathrm{~cm}$ de altura y poco más de $2 \mathrm{~cm}$ de anchura en la parte inferior (fig. 2).

En su parte frontal muestra, algo difusas, las características típicas de la figura de Bes: corona de plumas, patas delanteras de la capa de piel de león colgando sobre el pecho, brazos a la altura de las ingles, piernas

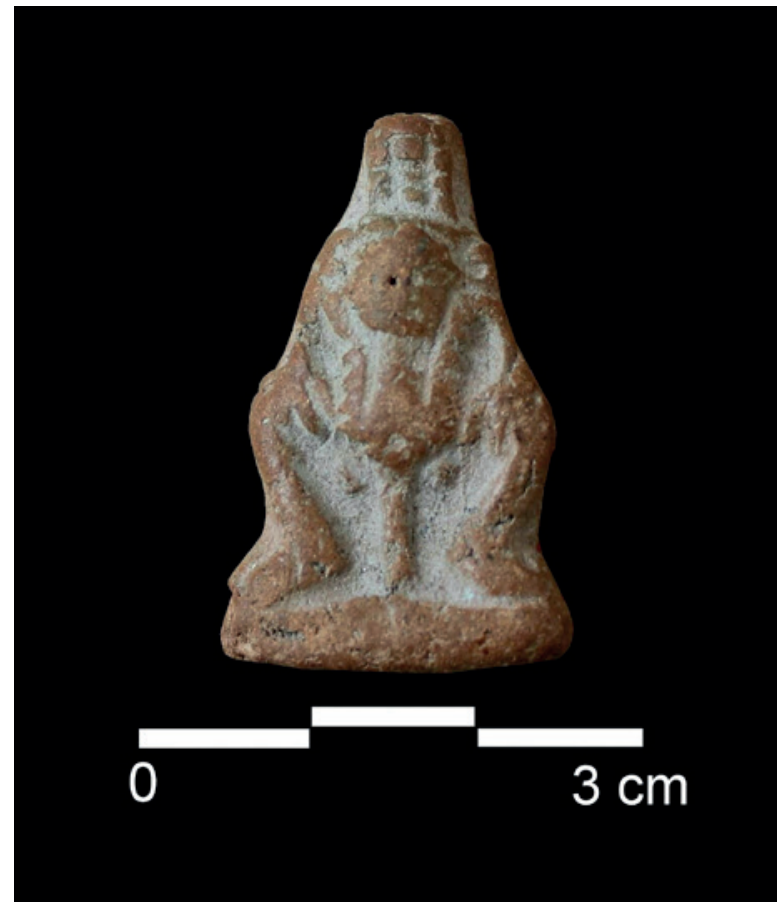

Figura 2. Amuleto de Bes procedente de Chipiona. 


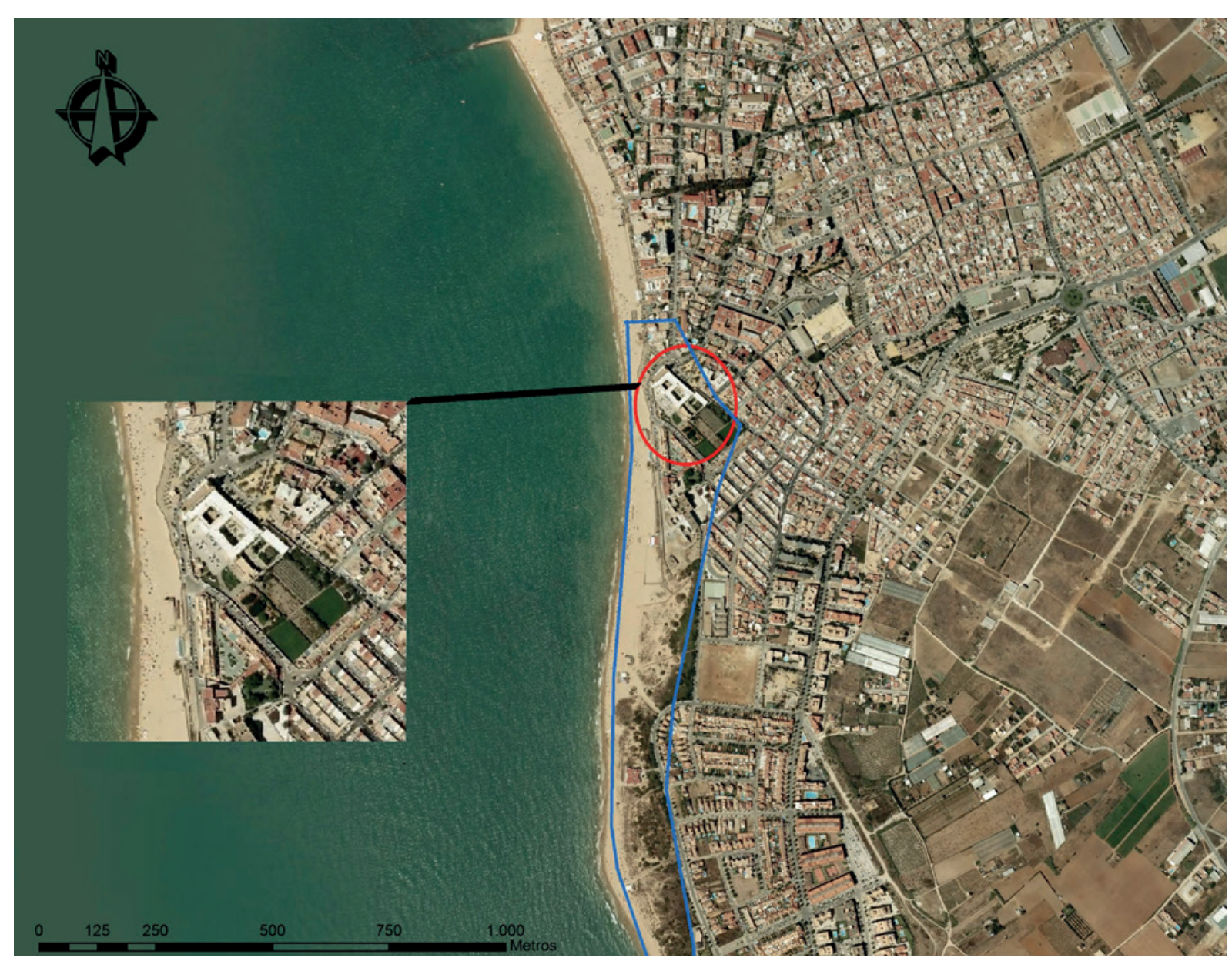

Figura 3. Plano de situación del santuario de Nuestra Señora de Regla. En su entorno más inmediato se han encontrado tumbas y hallazgos funerarios prerromanos y romanos dispersos.

flexionadas en posición agachada y sobresaliendo, entre ambas, la cola de dicha capa. En su mitad trasera, la pieza no ha sido tallada, destacando la ausencia de anilla.

$\mathrm{Su}$ hallazgo se realizó casualmente en las inmediaciones del santuario de Nuestra Señora de Regla en Chipiona, al noroeste de la provincia de Cádiz. El lugar se caracteriza por formar un pequeño promontorio natural que domina un amplio ancón que se extendía desde la Punta de Camarón hasta la del Perro (fig. 3), siendo la única zona sin plataforma rocosa en todo el término municipal. En la actualidad, desde allí se domina visualmente la entrada y salida del tráfico de embarcaciones por el Guadalquivir.

En lo que se refiere al registro material de las inmediaciones del santuario de Nuestra Señora de Regla nos encontramos con dos problemas importantes. Por un lado, la zona se caracterizaba por estar formada por cordones de dunas eólicas, también conocidas como voladeras, por lo que la visualización superficial de cualquier tipo de vestigio se presentaba prácticamente imposible. Además, habría que unir la pronta urbanización del lugar, lo que imposibilitó, al menos desde principios del siglo XX, el reconocimiento arqueológico del terreno. Por otra parte, contamos tan solo con dos excavaciones de urgencia practicadas en el lugar y una serie de testimonios escritos sobre los hallazgos fortuitos producidos desde mediados del siglo XVII. La mayor parte de estas fuentes aluden a la aparición de numerosos enterramientos, en su mayoría atribuibles a época romana (Carmona 1635-1639: 248; Alcázar et al. 1994: 36-47; Aracil y Martínez 1909; Madrazo 1884: 191), a excepción de dos sepulturas púnicas (Fernández-Chicarro 1962: 67; Tejera 1979: 149) ${ }^{1}$. Entre

1. Noticias a este respecto se publicaron en las siguientes ediciones: "Se descubren dos enterramientos de la época romana", 
dichos hallazgos destacan varias lápidas funerarias con epigrafía (González 1982: 57-58; Vives 1942: 45-46) y un vaso de terra sigillata gálica forma 37 de Dragendorff (Martínez Munilla 1949: 237-242).

De igual manera se han constatado varias esculturas marmóreas: una cabeza de Venus, «notable por la corrección de las líneas y la perfección del modelado» (Anónimo 1867: 231) y otras dos de difícil identificación aunque vinculadas al ámbito de la escultura decorativa y la ideal o mitológica (escultura erudita), fechadas entre los siglos I y II d.C. (comunicación personal de J. Beltrán).

Por lo que respecta a las dos intervenciones arqueológicas, la primera de ellas, practicada en 1993, dio como resultado la aparición de una necrópolis romana exclusivamente infantil datada entre los siglos III y IV d.C., la cual amortizaba un edificio fechado a mediados del siglo I d.C. (Alcázar et al. 1994: 36-47). Coetáneas a esta edificación, en 2009 se localizaron varias estructuras muy arrasadas, entre las que figuraba una pileta, al igual que en la anterior excavación, y un basurero con abundante material cerámico (Barreiro 2009).

\section{BES PROCEDENTE DE VIÑA DE LAS CÁNTARAS}

La segunda de las figuras aquí presentada se trata igualmente de un amuleto de Bes de 3,5 cm de altura y escasos $2 \mathrm{~cm}$ de anchura (fig. 4). Elaborado en pasta vítrea con una capa de vidriado azul, se encuentra realizada al detalle tanto por delante como por detrás, siendo en esta última cara donde presenta una anilla vertical para insertar por ella el cordón del colgante del que habría de pender.

Descrita de arriba hacia abajo, en su cabeza observamos la mayor singularidad, pues no ha sido representada la típica corona de plumas, mientras que en el resto del cuerpo presenta características propias de su figura: ceño fruncido y remarcado, amplia barba, piel de león con las patas delanteras anudadas sobre su pecho, vientre rechoncho, extremidades cortas con las manos sobre los muslos y piernas flexionadas. A pesar de no tener su usual corona de plumas, el resto de características observables permiten asegurar que se trata de Bes, lejos de representaciones similares de sátiros y patecos.

El amuleto se encontró en el yacimiento identificado como Viña de las Cántaras (Riesco 1987: 350-353;

La Vanguardia, 26/03/1960: 8; "Hallazgo arqueológico", ABC de Sevilla, 12/01/1979: 5.

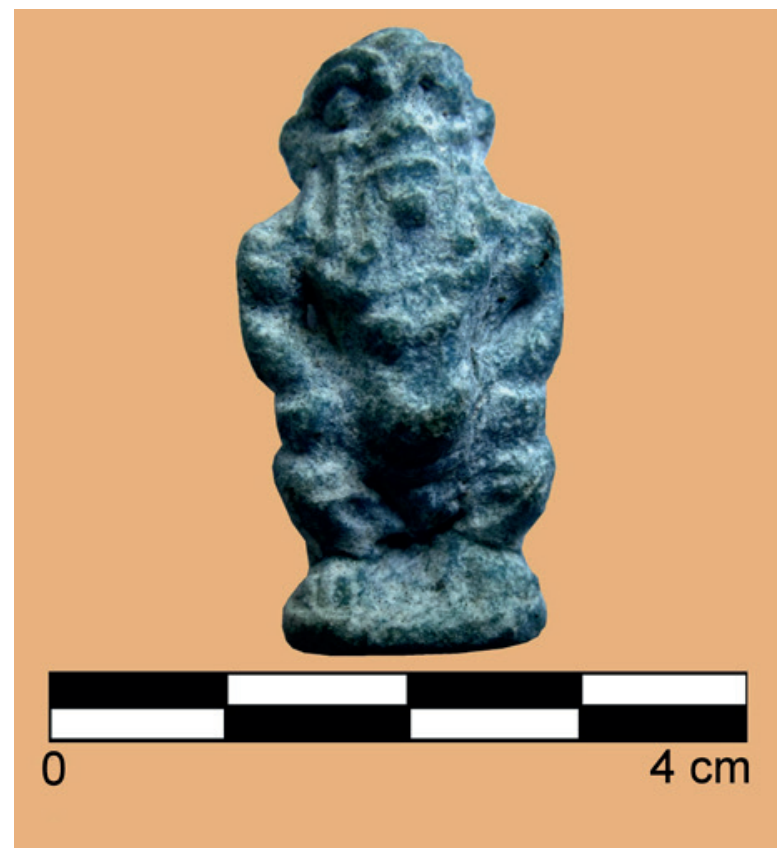

Figura 4. Amuleto de Bes procedente de Rota.

Ponsich 1991: 219), al noroeste del término municipal de Rota (Cádiz). Se sitúa sobre una pequeña elevación a 18 m s.n.m. (fig. 5), asentado sobre tierras formadas por conglomerados y areniscas muy carbonatados ("facies Ostionera"). El yacimiento linda al este con el camino de la Hijuela de Tía Pepa, que conduce a la Vereda de la Laguneta, a $620 \mathrm{~m}$ al norte. Como recurso hídrico cercano se encuentra el arroyo del Chacho, a 250 $\mathrm{m}$ al sureste.

El emplazamiento del que procede la pieza debe de ser diferenciado del yacimiento también denominado por algunos autores como Viña de las Cántaras (Bernal y Lagóstena 2004: 74; Bernal y Sáez 2006: 181184), situándose este último al este de Rota, lindando con el término de El Puerto de Santa María. Creemos que se trata de un error, pues dicho enclave ha venido denominándose en otras ocasiones en la bibliografía arqueológica como Los Cipreses, en el pago de Cantarranas (García Vargas 1998: 173-178; McClellan et al. 2010: 110).

El emplazamiento presenta en la actualidad un relleno de tierra para facilitar el cultivo de secano que en él se desarrolla, desfigurando notablemente la visibilidad que presentaba en las décadas anteriores. De igual manera, para facilitar el drenaje del terreno, se practicaron zanjas de metro y medio de profundidad con orientación norte-sur en toda la finca, desconociendo la afección que pudo sufrir el yacimiento. 


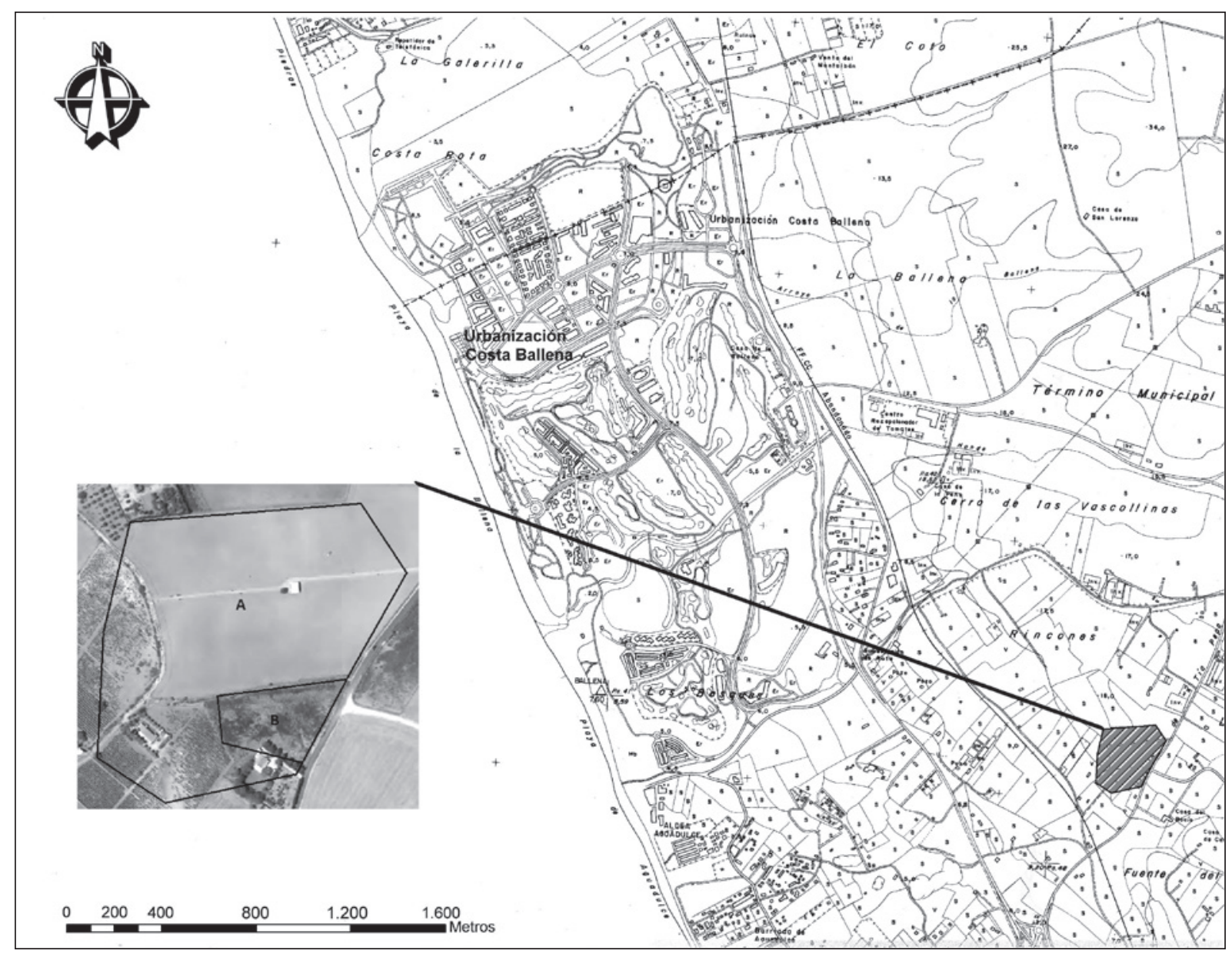

Figura 5. Plano de situación del yacimiento de Viña de las Cántaras. Se aprecian dos zonas diferenciadas: la zona doméstica con su actividad alfarera (A) y la pequeña necrópolis asociada (B).

La posible cronología de esta pieza viene marcada por los materiales hallados tanto en la prospección de 1987 (Riesco 1987: 350-353) como en la que se ha venido desarrollando entre 2010 y 2012 bajo la dirección de J. Rodríguez, siendo en su mayoría romanos, a excepción de algunas cerámicas realizadas a mano e instrumentos pulimentados, atribuidos cronológicamente al II milenio a.C. En cuanto a la datación de los primeros, el yacimiento presenta una dilatada cronología que va desde finales del s. I a.C. al VI d.C. (figs. 6-8). Son abundantes los fragmentos de vajilla fina o de semilujo (terra sigillata itálica, subgálica, hispánica, $A R S-A, C$ y $D$ y cerámica narbonense), al igual que los de mesa y cocina. No menos copiosos son los materiales relacionados con el almacenaje, las ánforas y dolia, sobresaliendo las primeras sobre las segundas, mayoritariamente en sus formas Dressel 7-11 y Beltrán IIB. El material constructivo está representado fundamentalmente por tegulae, ladrillos y opus signinum. Igualmente hemos podido observar numerosos fallos de cocción cerámicos, lo que evidencia una actividad artesanal vinculada a una posible villa, un taller alfarero o figlina, cuya producción se centra al menos en la fabricación de Dressel 7-11.

Por último, al sur de la delimitación dada al asentamiento, tras un pequeño arroyo, hemos podido localizar una zona de necrópolis. El agostado de los terrenos en los años setenta provocó la ruptura de diversas sepulturas y el esparcimiento de los huesos que ellas contenían. Según información proporcionada por el propietario de los terrenos existirían dos tipos de enterramientos, unos realizados en cistas y otros en tegulae. Del primero de ellos parece que aún se conserva una sepultura, construida sobre una fosa delimitada con piedra ostionera, cubierta por una gran losa. El cadáver se encontraba en decúbito supino con orientación 
norte-sur (pies-cabecera). Ignoramos el tipo de ajuar que contenía, por lo que no podemos precisar la cronología del mismo. El tipo de ritual empleado, la inhumación, tampoco nos ayuda a ello. Sabemos que a finales del s. II d.C. se constata un cambio en las costumbres funerarias en la Bética. La inhumación se hace más frecuente que la cremación, mientras que en el siglo precedente la proporción era inversa (Albertini 2005 [1923]: 115; Gestoso y López 2009: 43). Esta práctica funeraria no carece de relación con las creencias que se divulgaron sobre la vida futura, sobre la salvación eterna y sobre una posible resurrección de los cuerpos (Albertini 2005 [1923]: 115). A pesar de ello, la inhumación se practicaba con anterioridad, como se ha constatado en diversas necrópolis. Así por ejemplo, esta práctica la encontramos en Villarroya de la Sierra (Zaragoza) (Medrano y Sanz 2010: 276), en Baelo Claudia (Cádiz) (Sillières 1997: 202), en la necrópolis de la Boatella (Valencia) (Cebrián y Herreros 2008: 304), en la necrópolis de la calle Bellidos (Écija) (López y Tinoco 2007: 610), etc. Por su parte, las cremaciones continúan mucho más de lo que en principio habría cabido suponer (Vaquerizo 2002: 150). A falta de una actividad arqueológica que nos proporcione con mayor exactitud el inicio y el abandono de la misma, no podemos aventurar más que lo expuesto. No obstante más adelante volveremos sobre este y otros particulares a propósito de la cronología de ambos amuletos, cuestión que no es fácil de precisar.

\section{DIACRONÍA Y TRANSCULTURALIDAD DE LA FIGURA DE BES}

Las cuestiones geográficas, cronológicas y transculturales de esta deidad merecen una mención. Así, desde el siglo XIX la tradición historiográfica ha venido escribiendo sobre la figura de Bes en el antiguo Egipto en innumerables ocasiones $\mathrm{y}$, desde hace varias décadas, a propósito de su papel en el mundo cananeo del II y I milenios a.C. Síntesis de indudable valor son las elaboradas por V. Tran Tam Tinh (1986: 98-108) a propósito de Bes en el antiguo Egipto y por A. Hermary (1986: 108-1112) para el caso de Bes en el mundo fenopúnico. Sin embargo, son escasísimas las referencias sobre esta divinidad en el ámbito de influencia romana antes y después del cambio de era. Y si esto es aplicable a todo el Mediterráneo, la tendencia a publicar sobre asuntos como este en la península ibérica se agudiza si cabe, toda vez que hasta ahora sólo han sido halladas poco más de una veintena de representaciones de Bes (algunas no sin dudas) en amuletos, terracotas y escarabeos (Velázquez 2007). A esta complejidad hay que sumar la gran diversidad de representaciones y de soportes en que aparece, el amplio arco cronológico de las mismas, la gran cantidad de atribuciones otorgadas a esta peculiar divinidad, así como la transculturalidad que afectó a su culto y a la asimilación de la figura dentro del imaginario religioso de cada población. No obstante, un breve repaso por todas estas cuestiones puede permitirnos ver y advertir los problemas y las limitaciones a las que debe enfrentarse el investigador en un futuro próximo.

Ya desde los primeros momentos de la aparición de Bes en época Naqada existen dudas sobre su procedencia, tradicionalmente polarizado entre un origen centroafricano y otro propiamente egipcio. Así, quienes se posicionan a favor de esta última hipótesis argumentan que la frontalidad con la que suele aparecer no es exclusiva de Bes, sino que otras diosas como Hathor la presentan a veces del mismo modo, habiendo sido asimilado su enanismo desde bien pronto en diferentes culturas con connotaciones mágico-religiosas. Por su parte, quienes apoyan la idea de que Bes es centroafricano basan su razonamiento en las enormes similitudes con los pigmeos, quienes habrían habitado en época predinástica un territorio bastante amplio, incluyendo el propio Egipto, y no habrían sido reducidos a su territorio actual hasta momentos posteriores. Una buena visión de conjunto sobre esta problemática historiográfica puede verse en F. Velázquez (2007: 19-23).

No obstante, más allá de estos inicios, que nos dejan actualmente más dudas que respuestas sobre si las representaciones en épocas tan tempranas son atribuibles a Bes o a seres enanos de rasgos grotescos, no es hasta el Imperio Nuevo cuando tenemos constancia del nombre de Bes por primera vez. Nuevamente es F. Velázquez quien mejor ha sabido sintetizar la cuestión de la unicidad o multiplicidad de identidades de las figuras enanas y grotescas halladas por los especialistas en el Antiguo Egipto, así como la multiplicidad de nombres para estas imágenes (Velázquez (2007: 12-19). Como bien comenta D. Gómez (2002: 89-90), será durante el Imperio Nuevo cuando Bes adquiera las características iconográficas que, en la mayor parte de los casos, han existido hasta época romana. Las identificaciones anteriores durante el predinástico y el Reino Antiguo parten precisamente del parecido iconográfico y de las atribuciones que Bes tendrá en épocas posteriores, cuando el nombre acompaña a su figura. Esta metodología no supone sino abstraer un ideal de Bes al que se le buscan orígenes y evoluciones posteriores. Un excelente 


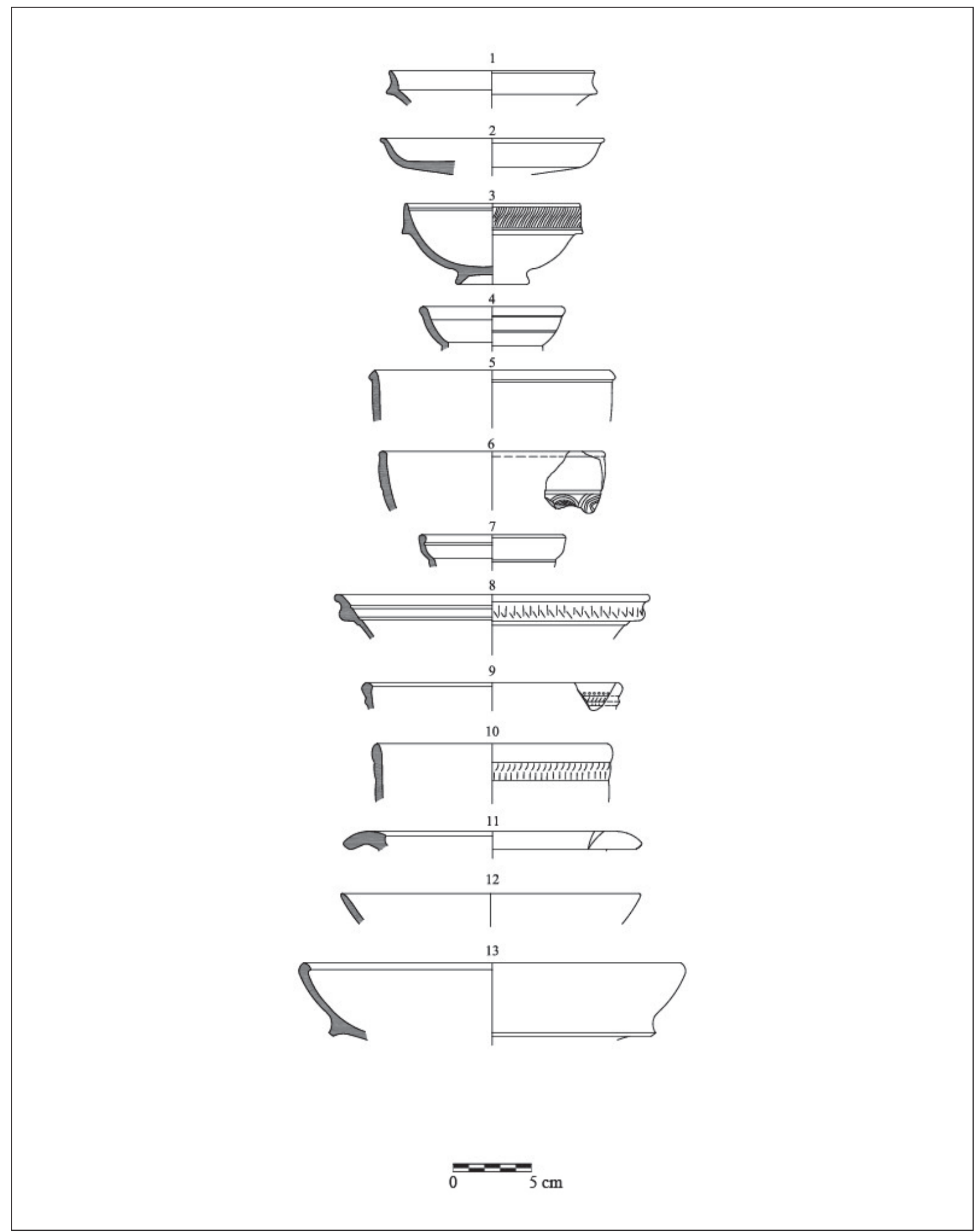

Figura 6. Cerámica de semi-lujo romana hallada en el yacimiento de Viña de las Cántaras. 1. TSI Consp. 23.2, 2. TSG Drag. 18, 3. TSG Drag. 24/25, 4. TSG Drag. 27, 5. TSG Drag. 37, 6. TSH Froma 37, 7. TSH Forma 27, 8. ARS-A Hayes 8A, 9-10. ARS-A Hayes 9A, 11. ARS-A Hayes 3, 12. ARS-C Hayes 50, 13. Hayes 23B. 
trabajo sobre la evolución iconográfica de esta divinidad es la tesis de J. Romano (1989). Para profundizar en su origen leonino nuevamente F. Velázquez (2007: 23-31). Así, en el Imperio Nuevo, a su conocida imagen enana con las piernas arqueadas, las manos en los muslos y la piel de león cayendo por la espalda asomando la cola por entre las piernas, se sumarán su barba, su corona de plumas, su faldellín, e incluso a veces alas, del mismo modo que romperá su peculiar frontalidad en otras ocasiones.

Posteriormente, será a partir de época saíta cuando la iconografía de Bes vuelva a mostrar cambios en la barba, la cual terminará en pequeños bucles; la cadera, que se verá rodeada de un cordón; y la piel de león, que ahora tendrá sus cuartos delanteros sobre su pecho asomando Bes la cabeza por una abertura en la piel (Velázquez 2007: 29-30; Gómez 2002: 94). Por lo que respecta a la corona de plumas, que algunos relacionan con cultos de fertilidad, muestra dos tipologías opuestas. Por un lado, esta corona es representada con todo detalle, mientras que en otros casos el tocado es reconocible únicamente por la base que la sustenta, existiendo ambas iconografías en época ptolemaica y en el mundo romano (Arroyo 2007: 21).

Al igual que con respecto a su iconografía, también las atribuciones dadas a Bes ganan en complejidad y diversidad cuanto más se acerca su presencia a la época helenística y romana. Así, la posible imagen de Bes en época predinástica habría estado asociada a contextos mágico-religiosos exteriorizados a través de las danzas quizás con un carácter protector de la fecundidad y del nacimiento, siendo estas danzas escenificadas por estos pigmeos con máscara y piel de león, en una referencia totémica a la divinidad (Toro 2006: 130). Pero esta unidad de criterio en las atribuciones dadas a Bes vuelve a verse modificada con el paso de los siglos. No obstante, a partir del III Período Intermedio y en época grecorromana, Bes no sólo será asociado con el culto a la fertilidad y al parto, sino que irá haciendo suyas las atribuciones de otros dioses, convirtiéndose en una deidad panteísta (Gómez 2002: 92; Kákosy 2002; Toro 2006; Marco 2007: 25), ampliando sus características y cobrando importancia su figura en asociación con divinidades como Horus, Amón-Ra, Homerty o Haroeris, cuando no sustituyendo a otras como Shu. De igual modo, la relación de Bes con la fertilidad, el nacimiento y la protección tras el parto de madres e hijos se hará en estos momentos marcadamente más sexual, como se desprende del carácter itifálico del Bes panteísta y de la asociación de su imagen con figuras fálicas en numerosas cámaras de época ptolemaica halladas en Saqqara.
Esta relación con la sexualidad y el erotismo puede tener sus antecedentes en el Imperio Nuevo si se interpretan como prostitutas a las danzarinas desnudas con representaciones de Bes tatuadas en sus muslos, denotando el carácter erótico de Bes como divinidad propiciadora del placer sexual. Por último, y siguiendo este orden diacrónico, pudo haber tenido también cualidades oraculares en época ya tardorromana (Gómez Lucas 2002: 92-95).

Como vemos, el nacimiento y evolución iconográfica y cultual de Bes presenta una multiplicidad de aspectos que no deben ser considerados de manera monolítica. A esto hay que sumar para el propósito que aquí nos ocupa, saliendo del marco geográfico egipcio, que el panorama se hace más complejo con la utilización por parte de la población cananea de esta divinidad por las costas mediterráneas en su proceso de expansión colonial al introducir a Bes en su religiosidad popular desde el II milenio a.C. (Gómez 2002: 92-105).

Como es bien sabido, fue la población fenicia la que introdujo el culto a Bes en la península ibérica, y con más profusión en la isla de Ibiza. Pero de todos los atributos iconográficos y cultuales ¿cuáles pasaron el filtro de la mentalidad religiosa cananea y cuáles no? Hasta el momento, el registro arqueológico nos permite sostener que la tradición fenopúnica pudo haber idealizado a Bes como una divinidad relacionada con la fertilidad y el erotismo e, incluso, como "señor de los animales" (Gómez 2002: 102 y 110; Velázquez 2007: 58). Pero aparte de estas cualidades más marginales sobre el significado iconográfico de Bes, las que sí primaron por encima de otras fueron sus características protectoras y apotropaicas tanto en la vida como en la muerte, al aparecer exvotos con su figura en varios santuarios costeros donde era tradicional la ofrenda de objetos por parte de los navegantes al partir o al arribar a salvo a la costa. Este sería el caso por ejemplo del santuario de la cueva de Gorham, en Gibraltar (Belén 2000; Belén y Pérez 2000). También aparece en varios amuletos encontrados como ajuar en diversas tumbas de Cartago (Vercoutter 1945: 281 y ss.; Lancel 1994: 73-74), en el tofet de Sulcis (Bartoloni 1973: 188, 12, lám. LVI, 9) y en diversos yacimientos de la península ibérica aquí tratados. También a tener en cuenta es el hallazgo aparecido en el mismo tofet de Sulcis de una moneda con la representación de Bes procedente de Ibiza y datable entre los siglos III-I a.C. (Acquaro 1973: 205-206, lám. LXIV).

Ante este panorama diacrónico, transcultural y geográficamente extenso, para algunos investigadores «...lo que el conocimiento de Bes ha ganado en extensión, lo ha perdido en profundidad y parece haberse 


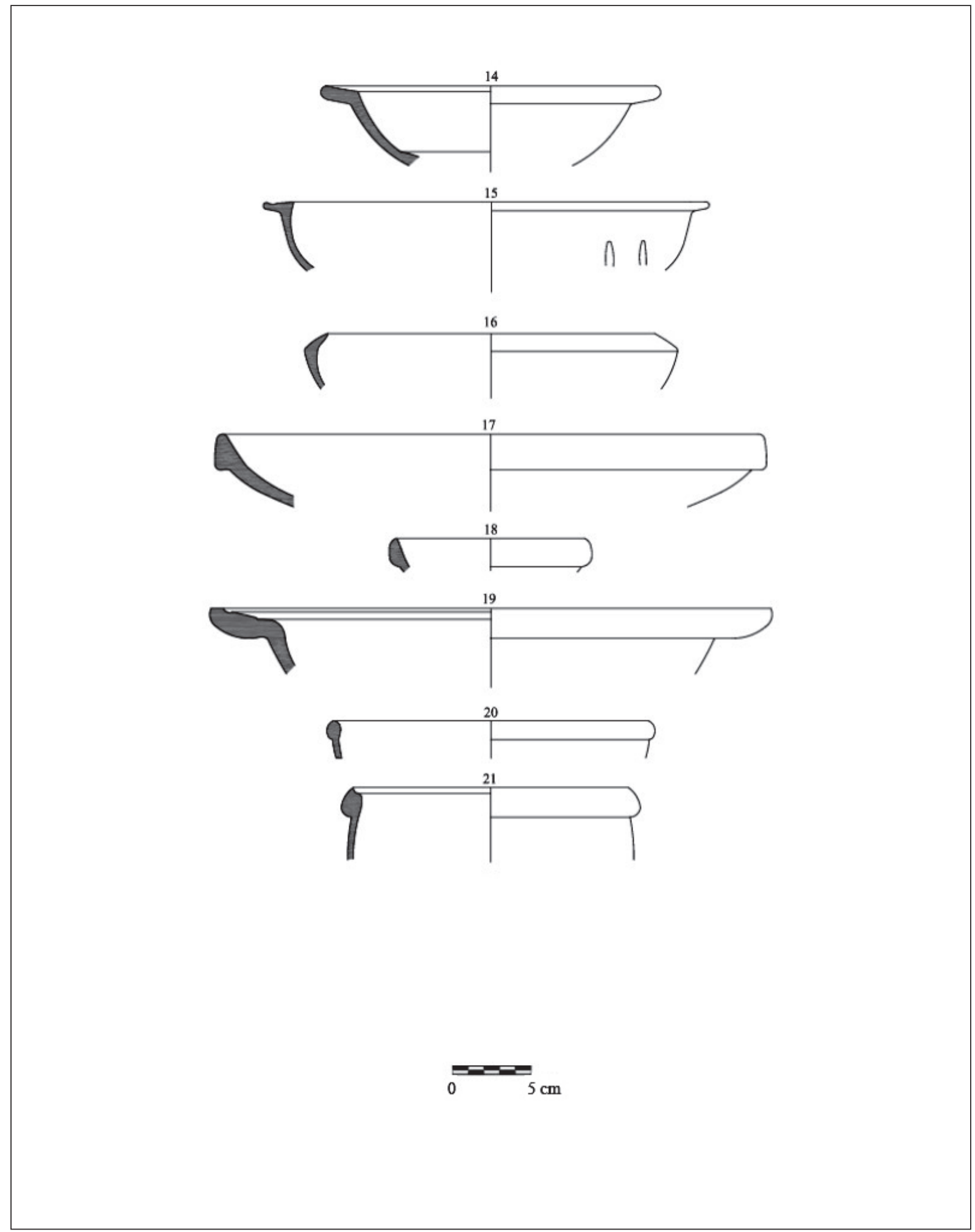

Figura 7. Cerámica de semi-lujo y común romana procedente de Viña de las Cántaras. 14. ARS-A/D Hayes 6, 15. ARS-D Hayes 59A, 16. ARS-D Hayes 61A, 17. ARS-D Hayes 61B, 18. ARS-D Hayes 99A, 19. ARS-D Hayes 59A, 20. Narbonense Lam. 1/3, 21. Hayes 197/Ostia III. 
convertido en un icono que representa en un sentido muy amplio la conjuración de lo malo y el deseo de atraer para sí lo bueno...»(Gómez 2002: 110-111). De la misma idea participa A. Alvar, anotando que su uso se podría haber extendido en el Mediterráneo occidental hasta el cambio de era debido a que en el aparato teológico egipcio había hueco para la creencia en el mal de ojo, y representaciones de algunas de las divinidades que funcionaban como protectoras del aojo, como el dios enano Bes o el ojo de Horus, eran parte de la mercancía con la que los fenicios comerciaban por todo el Mediterráneo; el uso de amuletos con miniaturas de Bes se puede rastrear en Roma hasta, al menos, el siglo I d.C. (Alvar 2010: 69).

El propio A. Alvar nos ha corroborado que no hay manera de saber si estos amuletos pompeyanos de Bes publicados por U. Pannuti (1983: figs. 110-111 y 355 357) son púnicos o romanos, puesto que todos los hallazgos son del siglo XIX y nada se especifica de su cronología, siendo el siglo I d.C. en todo caso una fecha ante quem. La mayoría de los amuletos sin embargo presentan como característica más notable la ausencia de corona de plumas, igual que el ejemplar de Rota. Nos encontramos, por tanto, ante uno de los sempiternos problemas metodológicos de la arqueología. A saber, que cuantas más particularidades nos encontremos en el registro, más difícil será realizar generalizaciones a partir de todos los hallazgos, y sus características irán diluyéndose hasta permitirnos solamente tratar a piezas como estas como "figuras apotropaicas". No obstante, hay que realizar un esfuerzo por intentar escudriñar dentro del registro arqueológico qué parámetros nos permiten inferir unas cualidades concretas y por qué.

\section{EL USO DE LOS AMULETOS DE BES EN LA PENÍNSULA IBÉRICA}

Gran parte de esta labor ya ha sido realizada por F. Velázquez (2007) en una completa y actualizada monografía sobre el dios Bes. En ella, la autora recoge, sin contar con la peculiaridad de la isla de Ibiza, un total de veinte representaciones de esta divinidad, la mayor parte de ellas en yacimientos de tradición fenopúnica, a los que se suman los dos del presente estudio. De todos ellos, las escasas excepciones que no se han hallado en sitios de tradición semita son el escarabeo de ámbar de Rosas, y las terracotas de Ullastret y Corral de Saus (Velázquez 2007: 95).

Por otra parte, existe una estrecha relación entre algunos tipos de soporte sobre el que aparece reflejada su figura y el contexto de su hallazgo. Así, de los doce lugares en los que se han encontrado representaciones de Bes en la península ibérica, se han hallado nueve amuletos (a los que nosotros hemos sumado estos dos nuevos testimonios y cinco piezas más), ocho terracotas, tres escarabeos y un vaso de alabastro. Poniendo en relación dichos soportes y sus contextos se observa, por ejemplo, que todos los amuletos han sido encontrados en necrópolis menos el ejemplar de La Fonteta, mientras que todos los escarabeos han sido localizados sin excepción en santuarios. Mención aparte merecen las terracotas, pues han sido recuperadas tanto de lugares de hábitat, como de favissae e incluso de tumbas (Velázquez 2007: 95).

Para el caso concreto de los amuletos, tema que aquí nos ocupa, si bien en contextos como el de La Fonteta podemos decir que la figura de Bes pudo haber sido utilizada con características profilácticas en vida, lo cierto es que principalmente su uso es funerario, tratando de proteger al difunto en su viaje a la otra vida, por lo que la debilidad ante lo desconocido y el intento por hacer frente a la misma se hace patente con el acompañamiento de figuras como la de Bes, pero ¿por qué su representación?

\section{UNA EXPLICACIÓN BIOLOGICISTA PARA EL MAL DE OJO}

Es de sobras conocido que piezas como los amuletos de Bes se engloban dentro de un aparente conjunto heterogéneo de símbolos que sirven como previsores contra el mal de ojo. En muchos de los casos conocidos este tipo de amuletos pretende hacer frente al aojamiento provocado de manera voluntaria o involuntaria por parte de quienes ponen su vista en una persona temerosa de ser "fascinada", especialmente mujeres y niños. Así, con tales objetos no se intenta otra cosa que apartar la mirada del fascinador hacia ellos, evitando cualquier posible mal para su portador. Sin embargo, lo que se suele pasar por alto es que, desde una perspectiva biologicista, muchas de las formas con que se pretende evitar este tipo de males entroncan con la percepción del peligro existente en la naturaleza que el ser humano y otros animales compartimos.

Ya Plutarco (Quaest. Con. 680C-683B) y Heliodoro (Etiopicas III, 7, 3 y ss.) intentaron dar explicación a esta creencia. Numerosos son los ejemplos en los que la mirada era la causante de este temor, y especialmente de particularidades de ésta. Así, la peculiar mirada es el denominador común del tuerto espartano 


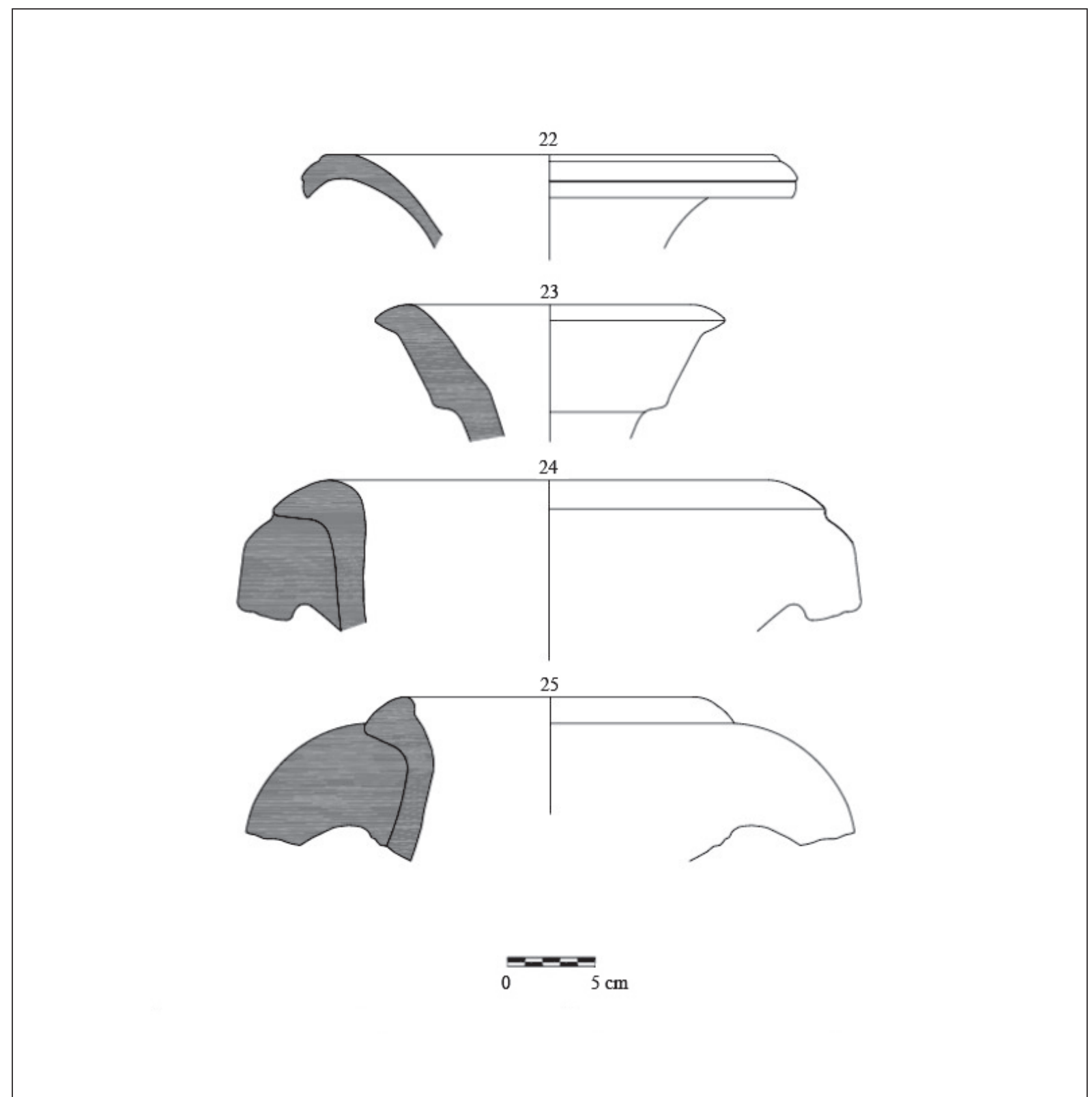

Figura 8. Tipologías anfóricas romanas presentes en Viña de las Cántaras. Desafortunadamente no se ha podido precisar la tipología de los fallos de cocción visibles en el yacimiento. 22. Ánfora T-7.4.3.3., 23. Ánfora Dr. 7-11, 24. Ánfora Beltrán IIb, 25. Ánfora Keay III.

Licurgo; de Oxilo, el guía de los Heraclidas al Peloponeso con uno o tres ojos; o de la Gorgona de mirada penetrante; así como de las atribuciones dadas a las de Tiberio y Augusto, entre otros. Como apunta E. Rey, la monoftalmia o la trioftalmia, así como tener doble pupila han sido características que han creado en el imaginario colectivo la concentración de una potencia en la mirada que fomentaba la penetración de sus efluvios en todo aquello sobre lo que se posase (Rey 1989: 230). Debido a esta creencia, quienes asumen como cierta la existencia del mal de ojo se preocupan por evitar dicha mirada, no sólo sobre sí mismos, sino por ejemplo sobre sus cosechas.

Una de las características especialmente relevante para nuestra interpretación es, en primer lugar, el porqué persuadirla. El hecho de que el observado se sienta 
intimidado establece una relación desigual entre el "aojador" y el "aojado". Esta relación desigual es perfectamente comparable a otro tipo de relaciones agresivas entre animales de una misma especie o de especies diferentes, en las que la mirada juega un papel fundamental. De hecho, los seres humanos suelen evitar la mirada sostenida entre extraños y quien la mantiene suele hacer prevalecer su autoridad. Y no sólo entre humanos, sino entre animales como los primates, los cuales perciben del mismo modo esta sensación. Es la mirada intensa y prolongada, puesta demasiado tiempo sobre otro individuo, la que puede tener como consecuencia la muestra de agresividad por parte del que mira o del que es mirado. Es el mismo procedimiento por el cual las mariposas con dibujos similares a unos ojos en sus alas consiguen por lo general ser menos atacadas por las aves que se sienten intimidadas al asimilar dichos dibujos con ojos de predadores vertebrados (Lyytinen et al. 2003; Kodandaramaiah 2009: 495-496).

En este sentido, el ser humano no se diferencia de otros muchos animales. Un claro ejemplo lo muestra un experimento llevado a cabo por el Evolution Behaviour Research Group de la Universidad de Newcastle (Bateson et al. 2006). Aprovechando una máquina de bebidas que se encuentra en el departamento de Psicología de dicha Universidad a la que tienen acceso 48 miembros, se quiso comprobar la reacción que causaba en los usuarios la colocación de varias imágenes ante la máquina. El experimento cobra más importancia ya que su uso es gratuito y la posibilidad de aportar un donativo por los gastos que conlleva su mantenimiento es anónima, debido a que la situación de la máquina hace imposible ver si quien la utiliza deja dinero o no en ella. Para ver la reacción de los compañeros del departamento, y sin que ellos lo supieran, se alternaron cada semana imágenes de ojos humanos y flores durante diez semanas. Los resultados fueron bastante significativos (fig. 9). Las semanas en que se colocaron junto a la máquina fotografías de personas mirando fijamente hacia delante se recaudó más dinero que aquellas semanas en que la imagen era floral. Y más significativo todavía fue que cuando las miradas eran masculinas se recaudaba más que cuando eran femeninas. De igual modo, cuanto más frontales eran las miradas, más dinero depositaba la gente en la máquina. Ante estos datos, los autores llegan a la conclusión de que las miradas hicieron a los usuarios sentirse observados y, por ello, inducidos a cooperar económicamente.

Mientras en lo anterior no existen diferencias entre humanos y otras especies, en lo que sí existe tal es en la utilización de cultura material para hacer frente a este tipo de miradas. Aun así, la base de esta práctica es puramente biológica y se expresa en los mismos términos en que cualquier animal actuaría contra este hecho. Además, la utilización de varios amuletos distintos en un mismo soporte potencia el efecto de todos ellos, por lo que no es inusual ver falos junto a higas, cornamentas, ojos, etc. De igual modo, su explicación es la misma. Si algo llama la atención de un individuo, son los elementos que representan el principal peligro del agresor: la cornamenta del toro o la dentadura del tiburón en los amuletos colgados, el empleo de serpientes, gallos y escorpiones en los mosaicos profilácticos, etc. Se trata de poner sobre aviso al fascinador con elementos propios del imaginario animalístico. También los animales apartan su mirada de la víctima ante sonidos y colores imprevistos. El caso de los llamativos colores de las alas de las mariposas hace creer a los pájaros que son elementos tóxicos. Nuevamente encontramos tintinabula, amuletos con cascabeles, amuletos de oro, fayenza, piedras preciosas o lazos rojos que no pretenden otra cosa que llamar la atención del agresor con elementos que en la naturaleza suelen poner en alerta a numerosas especies por su rareza.

Este breve repaso por algunos de los ejemplos más conocidos entre la bibliografía arqueológica y antropológica y su comparación biologicista es perfectamente aplicable a la figura de Bes. Su apariencia grotesca, su posible origen leonino, su frente arrugada, los ojos bien abiertos de manera frontal, su boca mostrando los dientes y la lengua, etc. recuerdan mucho a las muestras faciales de agresividad de simios y felinos. Además, el color turquesa pretende llamar la atención para que la mirada se centre rápidamente en él.

\section{LA CONTINUIDAD DE SU USO EN ÉPOCA ROMANA}

La bibliografía sobre Bes en la península ibérica ha girado siempre en torno al rol de esta divinidad en el mundo fenopúnico, mientras que cuando ha versado sobre su papel en el mundo romano ha mirado fuera de estas fronteras, con contadas excepciones aunque de manera meramente descriptiva (Jiménez 2004: 145146). Sin embargo, en la recopilación de ejemplares para el presente estudio hemos visto una fuerte continuidad en el uso de la imagen de Bes en época romana, sobrepasando incluso el cambio de era.

Así, como comentamos anteriormente, de los dieciséis amuletos encontrados en la península ibérica, once han sido hallados en tumbas, a excepción del ejemplar 
de La Fonteta, que lo fue en un contexto de hábitat y la incierta procedencia de las piezas sevillanas, además de los 35 ejemplares procedentes de la necrópolis ibicenca de Puig dels Molins (Velázquez 2007: 129-151). De igual modo, todos se centran en yacimientos de tradición fenopúnica: Gadir (cinco), Sexi (dos), Carmo (uno), La Fonteta (uno), teniendo también conocimiento de la existencia de un ejemplar no perteneciente a este ámbito procedente de la necrópolis del Poble Nou (Villajoyosa, Alicante), pero donde han aparecido igualmente elementos de tradición púnica. Otro posible amuleto de Bes podría ser el hallado en la tumba 586 del Cabecico del Tesoro (Verdolay, La Alberca, Murcia), datable entre los siglos IV-III a.C. (García Cano 1997: 254-255) (tabla 1).

De estos diez amuletos publicados hasta la fecha (a excepción de los mal documentados sevillanos), la mitad procede del área de influencia gaditana y de la decena tres son datables en época romana, dos procedentes de Cádiz y uno de Carmona, cifras nada desdeñables para considerar que su uso en época romana sea una cuestión marginal.

El primero, proveniente de la playa de Santa María del Mar, se localizó junto a otros amuletos en un contexto no bien definido, pero fechado por sus autores en el siglo III a.C., gracias a los elementos del collar junto al que apareció el Bes (Jiménez 1971: 132, láms. XIII-XIV; Gamer-Wallert 1978: 78 y lám. 20-j); los otros dos, muy similares entre sí, se han localizado en la tumba 49 de las excavaciones realizadas en 1982 en la c/. García Escámez, y en la tumba 15 de la campaña llevada a cabo en 1985 en la Avda. de Andalucía (Perdigones et al. 1987: 73, fig. 5), en el interior de una inhumación infantil en ánfora junto a otros elementos de un collar, entre ellos amuletos fálicos, lo que en ningún caso puede hacer fechar el enterramiento antes del siglo II a.C. (Alvar 2010: 166). El cuarto ejemplar gaditano, procedente de la tumba 2 de Casa del Pino, se fecha en época púnica. En dicha tumba se encontró un collar con cuentas de cornalina y plaquitas de oro con una figurita de Bes estrangulando serpientes datable en el s. IV a.C. (Cervera 1923: 9, Lám. VI; Gamer-Wallert 1978: 78 y lám. 20-e).

Con respecto al amuleto procedente de la necrópolis de Carmona, se sabe de su existencia gracias a la noticia que publicase G. Bonsor en 1897, dando a conocer este y otros amuletos, entre ellos un pateco, un ara y dos falos de hueso y marfil que habían sido encontrados en el interior de una urna de incineración en una tumba familiar de época romana, concretamente del área de Campo Real, en el lugar llamado La

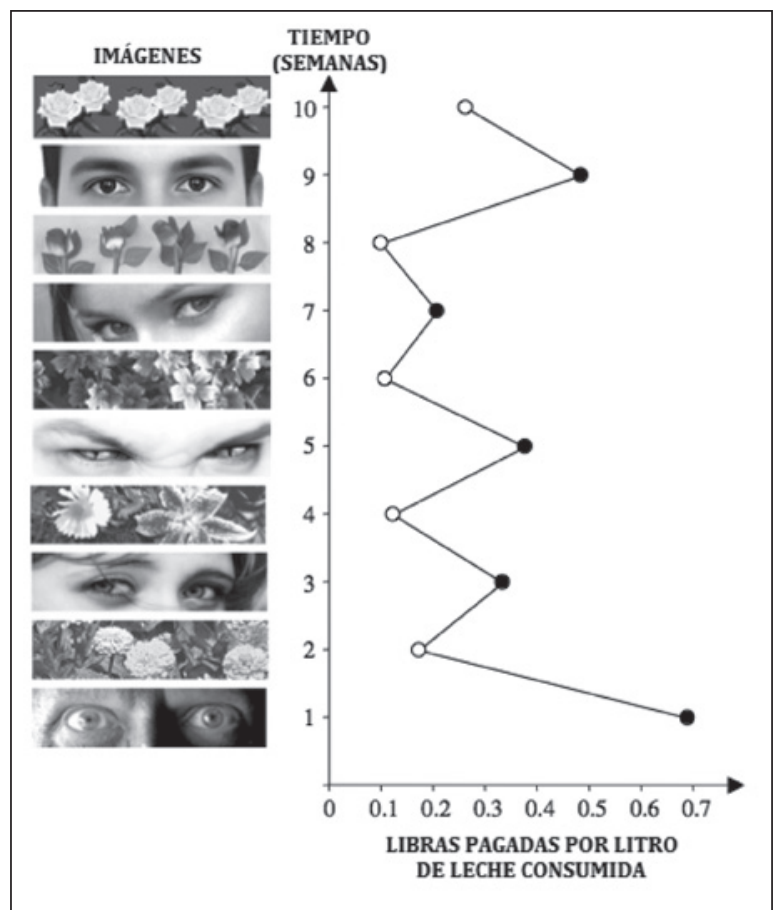

Figura 9. Resultados del experimento realizado por el Evolution Behaviour Research Group de la Universidad de Newcastle (a partir de Bateson et al. 2006).

Calderilla (Bonsor 1897: 231-233; Maier 1999: 52). A pesar de que Bonsor no ofreciera datación alguna, la tumba de carácter familiar encaja perfectamente con la fecha ofrecida por varios autores nunca anterior al siglo I d.C. De igual modo, la existencia de amuletos fálicos entre el ajuar de la incineración no permite llevar la cronología antes de época romana, pues este tipo de amuletos, así como representaciones de falos de manera variada por todo el Mediterráneo no se encuentran documentados con anterioridad al siglo II a.C. (Alvar 2010: 166 y ss.). Estaríamos así ante el primer amuleto de Bes fechable con total seguridad en época imperial en una necrópolis de claro sustrato púnico incluso tras el cambio de era, como han hecho notar numerosos investigadores (Bendala 1982; Vaquerizo 2012; Rodríguez et al. 2012). Lo mismo puede decirse para el caso de Gades, donde se observa una continuidad espacial y material en el uso de las necrópolis, utilizándose pozos y fosas para la amortización de los banquetes funerarios y manteniéndose la composición de los ajuares, aunque conviviendo con nuevas construcciones, caso de las piletas, en ritos igualmente de tradición semita (Niveau de Villedary y Blanco 2007: 219). Así pues, la evidencia material nos lleva a sostener sin ningún 
género de dudas que los habitantes de Cádiz en el s. II a.C. siguen sintiendo y continúan enterrándose como semitas, circunstancia que sólo variará cuando culmine el proceso de pérdida de identidad étnica de los gaditanos, lo que generalmente se sitúa hacia mediados del s. I a.C. Este hecho es la culminación del proceso paulatino de asimilación de las elites provinciales mediante la adopción de elementos culturales romanos como la lengua, la escritura y la religión (Niveau de Villedary y Blanco 2007: 219).

No resulta por tanto extraño que el componente púnico siguiera latente bien entrada la romanización en ciudades como Gades y Carmo, ambas con un gran componente fenopúnico sin lugar a dudas en momentos anteriores.

La causa por la cual gozó de esta continuidad la figura de Bes tras el cambio de era quizás tenga respuesta, basada en el acabado de mencionar enorme peso semita de ambas ciudades durante todo el I milenio a.C., en que «estas divinidades no gozaron de un culto a nivel estatal, ni tuvieron consagrados grandes templos, ni fueron objeto de las complicadas especulaciones teológicas que ocuparon a las altas clases sacerdotales con otras divinidades, pero todo el mundo las tenía en un lugar cercano» (Gómez 2002: 111). Es probable que ésta sea la razón por la cual el culto de Bes tuvo tanto éxito y tan larga duración entre las poblaciones cananea y romana por todo el Mediterráneo. Como bien ha apuntado A. Alvar, el aspecto de Bes, enano, panzurrón, itifálico en ocasiones y con una expresión facial marcada, tuvo éxito en la iconografía de los amuletos en el mundo fenopúnico y romano (A1var 2010: 216). Sin embargo, desmarcándonos en este caso de la opinión de Alvar, no creemos que se trate de «exóticas importaciones provenientes de Egipto a la Vrbs, y no de estratos religiosos pre-romanos en letargo que se recuperan en el siglo I d.C.» (Alvar 2010: 262, nota 9). Como veremos, los hallazgos se fechan desde el siglo V a.C. hasta el I d.C. sin solución de continuidad. Y como queremos mostrar, el ejemplar procedente de Rota podría perfectamente datarse en momentos coetáneos a los del amuleto de Carmo.

\section{PROBLEMAS Y SOLUCIONES PARA LA DATACIÓN DE LOS DOS NUEVOS AMULETOS}

Los hallazgos puntuales realizados en superficie siempre cuentan con las limitaciones propias derivadas de este hecho. Los dos ejemplares procedentes de
Rota y Chipiona no son una excepción a esta norma generalizada. Con respecto a la última, como hemos comentado anteriormente, tuvo lugar en las inmediaciones del santuario de Nuestra Señora de Regla, y por paralelos con el resto de contextos de los amuletos de Bes de la península ibérica y, más concretamente, del área de influencia de Gadir/Gades, no podemos saber si procede de una tumba púnica o romana ya que desde finales del siglo XIX se conoce la existencia de sepulturas de ambos períodos en torno a este santuario.

Mejor suerte corre el ejemplar de Rota, aunque podríamos realizar ciertas matizaciones sobre el yacimiento del que procede. Usando el mismo planteamiento, no es posible atribuir con total claridad una fecha para este amuleto. Sin embargo, con los datos disponibles podemos barajar como más probable que proceda de un enterramiento de época ya imperial. De igual manera podemos plantear que el objeto en cuestión procede de una necrópolis, ya que, como comentamos anteriormente, el dueño de uno de los terrenos en los que se inscribe el yacimiento de Viña de las Cántaras nos informó de que al agostar el terreno salieron a la superficie huesos humanos y se encontró una tumba realizada en piedra ostionera.

En cuanto a la cronología del yacimiento, a excepción de algunos materiales propios del II milenio a.C., el resto nos indica que la villa estuvo en funcionamiento desde el siglo I a.C. hasta el VI d.C., pudiendo perfectamente fecharse en torno al cambio de era, como acabamos de ver a partir de los contextos de Carmona y de la Avda. de Andalucía de Cádiz. No obstante, y a falta de excavaciones, siempre cabe la posibilidad de que las tumbas anexas sean púnicas o republicanas pero, para apoyar esta hipótesis, hacen falta datos hasta el momento inexistentes. Si como pensamos, villa y necrópolis forman un todo coetáneo, la arqueología también nos ha legado información a favor de nuestra propuesta cronológica, ya que se conocen casos similares en la Bahía de Cádiz (área de la que no hay que desvincular en ningún caso a ambas localidades gaditanas aquí tratadas). Así no es para nada extraño encontrar villas de carácter alfarero con necrópolis asociadas cuya tradición arranca en época púnica y continúa durante los períodos republicano e imperial, como bien han demostrado A. M. Sáez y J. J. Díaz (2010) recientemente.

Además, la ausencia de plumas en su corona acerca tipológicamente a este ejemplar a los ya mencionados de época romana, que precisamente se caracterizan en 
Tabla 1. Tabla informativa sobre los amuletos de Bes hallados en la península ibérica.

\begin{tabular}{|c|c|c|c|c|c|c|}
\hline $\mathrm{N}^{\circ}$ & Yacimiento & Localidad & Contexto & Cronología & Características & Bibliografía \\
\hline 1 & La Fonteta & $\begin{array}{l}\text { Guardamar } \\
\text { del Segura } \\
\text { (Alicante) }\end{array}$ & $\begin{array}{l}\text { Zona de } \\
\text { asentamiento }\end{array}$ & $\begin{array}{l}\text { En tomo a los } \\
\text { siglos VII-VI } \\
\quad \text { a.C. }\end{array}$ & $\begin{array}{l}\text { Figura en posición flexionada con } \\
\text { corona de plumas }\end{array}$ & $\begin{array}{l}\text { González Prats 1999-2000; } \\
\text { Velázquez Brieva 2007: } \\
\text { 89, lám. XXVI, fig. } 4\end{array}$ \\
\hline 2 & $\begin{array}{l}\text { Necrópolis } \\
\text { de Poble Nou }\end{array}$ & $\begin{array}{l}\text { Villajoyosa } \\
\text { (Alicante) }\end{array}$ & $\begin{array}{l}\text { Tumba de } \\
\text { incineración }\end{array}$ & Época púnica & $\begin{array}{l}\text { Esfinge alada con cabeza de Bes y } \\
\text { corona de plumas }\end{array}$ & $\begin{array}{l}\text { Velázquez Brieva } \\
\text { 2007: } 86\end{array}$ \\
\hline 3 & $\begin{array}{l}\text { Necrópolis } \\
\text { de Puente } \\
\text { de Noy }\end{array}$ & $\begin{array}{l}\text { Almuñécar } \\
\text { (Granada) }\end{array}$ & $\begin{array}{l}\text { Tumba } 5 \text { de inhuma- } \\
\text { ción de la zona B }\end{array}$ & Siglo V a.C. & $\begin{array}{l}\text { Placa rectangular de esteatita con } \\
\text { restos de vidriado verde con Bes } \\
\text { entre animales }\end{array}$ & $\begin{array}{l}\text { Molina et al. 1982: 49, } \mathrm{n}^{\circ} \\
\text { 19, fig. 18; Molina y Pa- } \\
\text { dró 1983: 113, n 11, fig. } \\
\text { 2; Velázquez Brieva 2007: } \\
\text { 87, lám. XXVI, fig. } 1\end{array}$ \\
\hline 4 & $\begin{array}{l}\text { Necrópolis } \\
\text { de Puente } \\
\text { de Noy }\end{array}$ & $\begin{array}{l}\text { Almuñécar } \\
\text { (Granada) }\end{array}$ & $\begin{array}{l}\text { Tumba } 5 \text { de inhuma- } \\
\text { ción de la zona B }\end{array}$ & Siglo V a.C. & $\begin{array}{l}\text { Figura de fayenza con restos de vi- } \\
\text { driado verde en posición flexio- } \\
\text { nada }\end{array}$ & $\begin{array}{l}\text { Molina et al. 1982: 50, }{ }^{\circ} \\
\text { 25, fig. 18; Molina y Padre) } \\
\text { 1983: 113, } \mathrm{n}^{\circ} 11 \text {, fig. 2; Ve- } \\
\text { lázquez Brieva 2007: } 87\end{array}$ \\
\hline 5 & $\begin{array}{l}\text { Necrópolis } \\
\text { de Regla }\end{array}$ & $\begin{array}{l}\text { Chipiona } \\
\text { (Cádiz) }\end{array}$ & $\begin{array}{c}\text { Tumba } \\
\text { indeterminada }\end{array}$ & $\begin{array}{c}\text { Sin } \\
\text { determinar }\end{array}$ & $\begin{array}{l}\text { Figura de adobe en posición } \\
\text { flexionada con corona de plumas }\end{array}$ & Inédito \\
\hline 6 & Gadir & Cádiz & $\begin{array}{l}\text { Tumba } 2 \text { de } \\
\text { inhumación de } \\
\text { Casa del Pino }\end{array}$ & $\begin{array}{l}\text { Primera mitad } \\
\text { del siglo IV a.C. }\end{array}$ & $\begin{array}{l}\text { Lámina de oro con representación } \\
\text { de Bes agarrando serpientes }\end{array}$ & $\begin{array}{l}\text { Cervera 1923: 8-9, lám. } \\
\text { VI; García Martínez 2001: } \\
\text { 70, nº } 02.71\end{array}$ \\
\hline 7 & Gadir & Cádiz & $\begin{array}{l}\text { Playa de Santa } \\
\text { María del Mar }\end{array}$ & Siglo III a.C. & $\begin{array}{l}\text { Figura en posición flexionada sin } \\
\text { corona de plumas }\end{array}$ & $\begin{array}{l}\text { Gamer-Wallert 1978: 78, } \\
\text { taf. 20J, P; García Martí- } \\
\text { nez 2001: 54, nº } 02.44\end{array}$ \\
\hline 8 & Gadir & Cádiz & $\begin{array}{l}\text { Procedencia } \\
\text { desconocida }\end{array}$ & $\begin{array}{l}\text { Sin } \\
\text { determinar }\end{array}$ & Sin determinar & $\begin{array}{l}\text { García Martínez 2001: } \\
224, n^{\circ} 47.13\end{array}$ \\
\hline 9 & Gadir & Cádiz & $\begin{array}{l}\text { Tumba } 49 \text { en } \\
\text { C/ García Escámez }\end{array}$ & $\begin{array}{l}\text { Época romana } \\
\text { indeterminada }\end{array}$ & $\begin{array}{l}\text { Figura fracturada por la mitad, } \\
\text { conservándose la superior sin co- } \\
\text { rona de plumas }\end{array}$ & $\begin{array}{l}\text { García Martínez 2001: 56- } \\
\text { 57, n 02.46; Velázquez } \\
\text { Brieva 2007: } 88\end{array}$ \\
\hline 10 & Gadir & Cádiz & $\begin{array}{l}\text { Tumba 15. Ánfora } \\
\text { con inhumación in- } \\
\text { fantil en Avenida de } \\
\text { Andalucía }\end{array}$ & $\begin{array}{l}\text { Época romana } \\
\text { indeterminada }\end{array}$ & $\begin{array}{l}\text { Figura en posición flexionada sin } \\
\text { corona de plumas }\end{array}$ & $\begin{array}{l}\text { Perdigones, Troya y Mu- } \\
\text { ñoz 1987: 73, fig. 5; Gar- } \\
\text { cía Martínez 2001: 45, n } \\
02.31\end{array}$ \\
\hline 11 & $\begin{array}{l}\text { Viña de las } \\
\text { Cántaras }\end{array}$ & $\begin{array}{l}\text { Rota } \\
\text { (Cádiz) }\end{array}$ & $\begin{array}{l}\text { Tumba de inhuma- } \\
\text { ción en una villa al- } \\
\text { farera }\end{array}$ & $\begin{array}{l}\text { Época romana } \\
\text { indeterminada }\end{array}$ & $\begin{array}{l}\text { Figura en posición flexionada sin } \\
\text { corona de plumas }\end{array}$ & Inédito \\
\hline 12 & Carmo & $\begin{array}{l}\text { Carmona } \\
\text { (Sevilla) }\end{array}$ & $\begin{array}{l}\text { Tumba de incinera- } \\
\text { ción familiar de La } \\
\text { Calderilla }\end{array}$ & $\begin{array}{l}\text { Época romana } \\
\text { imperial }\end{array}$ & $\begin{array}{l}\text { Figura en posición flexionada sin } \\
\text { corona de plumas }\end{array}$ & $\begin{array}{l}\text { Bonsor 1897: 231-233, } \\
\text { fig. } 1\end{array}$ \\
\hline 13 & $\begin{array}{c}\text { Sin } \\
\text { determinar }\end{array}$ & $\begin{array}{l}\text { Provincia } \\
\text { de Sevilla }\end{array}$ & $\begin{array}{l}\text { Sin determinar. Co- } \\
\text { lección particular }\end{array}$ & $\begin{array}{l}\text { Sin } \\
\text { determinar }\end{array}$ & $\begin{array}{l}\text { Figura con las manos en las cade- } \\
\text { ras sin corona de plumas }\end{array}$ & $\begin{array}{l}\text { García Martínez 2001: } \\
224, n^{\circ} 47.13\end{array}$ \\
\hline 14 & $\underset{\text { determinar }}{\operatorname{Sin}}$ & $\begin{array}{c}\text { Sin } \\
\text { determinar }\end{array}$ & $\begin{array}{l}\text { Sin determinar. Mu- } \\
\text { seo Arqueológico de } \\
\text { Sevilla: ROD } 2415\end{array}$ & $\begin{array}{c}\text { Sin } \\
\text { determinar }\end{array}$ & $\begin{array}{l}\text { Figura de pasta vidriada verde } \\
\text { fracturada a la altura de las piernas } \\
\text { sin corona de plumas }\end{array}$ & $\begin{array}{l}\text { García Martínez 2001: } \\
232\end{array}$ \\
\hline 15 & $\begin{array}{c}\text { Sin } \\
\text { determinar }\end{array}$ & $\begin{array}{l}\text { Sin } \\
\text { determinar }\end{array}$ & $\begin{array}{l}\text { Sin determinar. Mu- } \\
\text { seo Arqueológico de } \\
\text { Sevilla: ROD } 2416\end{array}$ & $\begin{array}{c}\text { Sin } \\
\text { determinar }\end{array}$ & $\begin{array}{l}\text { Figura de pasta vidriada azul clara } \\
\text { con la mano derecha hacia su to- } \\
\text { cado de plumas sujetando un cu- } \\
\text { chillo o una pluma. Fracturada por } \\
\text { las piernas y parte de un brazo }\end{array}$ & $\begin{array}{l}\text { García Martínez 2001: } \\
232\end{array}$ \\
\hline 16 & $\begin{array}{c}\text { Sin } \\
\text { determinar }\end{array}$ & $\begin{array}{c}\text { Sin } \\
\text { determinar }\end{array}$ & $\begin{array}{l}\text { Sin determinar. Mu- } \\
\text { seo Arqueológico de } \\
\text { Sevilla }\end{array}$ & $\begin{array}{c}\text { Sin } \\
\text { determinar }\end{array}$ & $\begin{array}{l}\text { Figura que conserva parte de su vi- } \\
\text { driado azul oscuro. Fracturada en } \\
\text { su mitad inferior no presenta to- } \\
\text { cado alguno }\end{array}$ & $\begin{array}{l}\text { García Martínez 2001: } \\
\text { 232-233 }\end{array}$ \\
\hline
\end{tabular}


todos los casos por esta particularidad, la cual no presentan los ejemplares de época púnica, a excepción del procedente de la playa de Santa María del Mar, fechado en el siglo III a.C. a partir del ajuar. ¿Quizás pudiera ser de comienzos de la época republicana?

Futuras intervenciones confirmarán nuestra hipótesis o por el contrario darán a conocer etapas anteriores de uso de la villa que, de igual modo, darían una cronología coherente para las tumbas.

\section{A MODO DE CONCLUSIÓN}

En vista de todo lo anterior, con los resultados precedentes pretendemos poner de relieve la importancia de Bes en el área de influencia de la Gades romana, cuestión hasta ahora que ha pasado prácticamente desapercibida entre los especialistas.

No obstante Gades o Carmo no son una excepción en el área mediterránea. El culto a Bes y la importancia de su representación en soportes de diferente tipo, incluidos los amuletos, no desaparece durante el período romano. Así, la presencia de Bes en el posible Iseum de Bithia (Agus 1983; Garbati 2009) y en el famoso oráculo tardoantiguo de Abydos (Dunand 1997), por citar sólo dos de los ejemplos más conocidos, nos indican que el culto a esta divinidad seguía latente en el Mediterráneo tras el cambio de era, hasta tal punto que autores como Tran Tam Tinh consideran que el verdadero momento de apogeo del culto a Bes en el antiguo Egipto se da en época romana (Tran Tam Tinh 1986: 108). No obstante, no es posible confirmar esta interpretación para el caso de las ciudades aquí tratadas.

Los datos nos indican que la aparición de estos amuletos suele darse en lugares de tradición fenopúnica, por lo que es muy probable que las poblaciones semitas hiciesen perdurar la costumbre de enterrar a sus difuntos con este tipo de amuletos bien a través del comercio romano en la zona bien a través de la compra de éstos en talleres locales, ya que ejemplares como el de Carmona y el de la gaditana playa de Santa María son muy semejantes entre sí como para poder plantear la posibilidad de estar ante reproducciones de un mismo artesano o taller.

Sin embargo, nos tememos que para resolver algunos de los interrogantes planteados en las líneas precedentes, como el de las cronologías de los amuletos de Chipiona y Rota la solución pasa por practicar excavaciones que nos permitan resolver de una vez por todas estas limitaciones metodológicas.

\section{Agradecimientos}

El presente artículo ha sido elaborado dentro del marco del proyecto "Estudio de yacimientos arqueológicos y revisión de las cartas arqueológicas de los términos municipales de Sanlúcar de Barrameda, Chipiona y Rota (Cádiz). 2010-2012" bajo la dirección de Jesús Rodríguez Mellado.

La contribución de ambos autores se ha realizado dentro de los grupos de investigación TELLUS. Prehistoria y Arqueología en el Sur de Iberia (HUM-949) y De la Turdetania a la Bética (HUM-152).

Queremos expresar nuestro más sincero agradecimiento a José Beltrán por permitirnos utilizar datos extraídos de su conferencia inédita "Esculturas romanas de Regla: una visión general de los hallazgos”, en el seminario Primeras Jornadas Históricas de Regla (Chipiona, Cádiz) celebrado entre el 2 y el 5 de septiembre de 2008, así como a Francisco Rodríguez, Antón Alvar y Daniel González Acuña por su amabilidad y disposición para resolvernos algunas dudas sobre aspectos relativos a esta publicación. Cualquier error en estas líneas es responsabilidad única de sus autores.

\section{BIBLIOGRAFÍA}

Acquaro, E. (1973): "Una moneta ibicenca dal tofet di Sulcis". Rivista di Studi Fenici I, 2: 205-206.

Agus, P. (1983): "Il Bes di Bitia". Rivista di Studi Fenici XI, 1: 41-47.

Albertini, E. (2005 [1923]): El Imperio Romano. Sevilla, Padilla Libros.

Alcázar Godoy, J.; Suárez López, A. y Alarcón Castellano, F.J. (1994): "Enterramientos infantiles en ánforas romanas". Revista de Arqueología 164: 36-47.

Alvar Nuño, A. (2010): El mal de ojo en el occidente romano: materiales de Italia, Norte de África, Península Ibérica y Galia. Tesis doctoral, Universidad Complutense de Madrid. Publicada electrónicamente en http://eprints.ucm.es/11039/

Anónimo (1867): “Artes y Arqueología”. Revista de Bellas Artes 29: 231-232. Publicado electrónicamente en http://hemerotecadigital.bne.es/issue.vm? $\mathrm{id}=0003768711 \&$ search $=\&$ lang $=\mathrm{en}$

Aracil, A. y Martínez, R. (1909): Reseña histórica-descriptiva del Santuario y Convento de Nuestra Señora de Regla (Chipiona, Cádiz). Barcelona, Tipografía Católica.

Arroyo de la Fuente, M.A. (2007): "Evolución iconográfica y significado del Dios Bes en los templos 
ptolemaicos". Espacio, tiempo y forma (Serie II, Historia Antigua) 19-20: 13-40.

Barreiro Espinal, F. (2009): Memoria final de la excavación extensiva en el solar $n^{\circ} 86$ de la Avenida de Sevilla, Chipiona, Cádiz. Delegación en Cádiz de la Consejería de Cultura de la Junta de Andalucía. Exp. 496/08.

Bartoloni, P. (1973): "Gli amuleti punici del tofet di Sulcis". Rivista di Studi Fenici I, 2: 181-203.

Bateson, M.; Nettle, D. y Roberts, G. (2006): "Cues of Being Watched Enhance Cooperation in a Real-World Setting". Biology Letters 22, 2 (3): 412 414. http://www.staff.ncl.ac.uk/daniel.nettle/biology\%20letters.pdf [05/08/2012] doi: http://dx.doi. org/10.1098/rsbl.2006.0509.

Belén Deamos, M. (2000): "Itinerarios arqueológicos por la geografía sagrada del Extremo Occidente", en B. Costa y J. H. Fernández (eds.), Santuarios fenicio-púnicos en Iberia y su influencia en los cultos indígenas: 57-102. Ibiza, Museo Arqueológico de Ibiza y Formentera.

Belén Deamos, M. y Pérez, I. (2000): “Gorham's Cave, un santuario en el Estrecho. Avance del estudio de los materiales cerámicos", en Actas del IV Congreso Internacional de Estudios Fenicios y Púnicos, vol. II: 531-542. Cádiz (1995), Cádiz, Universidad de Cádiz.

Bendala Galán, M. (1982): "La perduración púnica en los tiempos romanos. El caso de Carmo". Huelva Arqueológica VI: 193-203.

Bernal Casasola, D. y Lagóstena Barrios, L. (2004): "Alfares y producciones cerámicas en la provincia de Cádiz. Balance y perspectivas", en L. Lagóstena y D. Bernal (eds.), Congreso Internacional Figlinae Baeticae. Talleres Alfareros y producciones cerámicas en la Bética romana (ss. II a.C.-VII d.C.): vol. I: 39-124. Cádiz (2003), Oxford, John W. Hedges.

Bernal Casasola, D. y Sáez Romero, A. M. (2006): “Infundibula gaditana. Acerca de los vasos troncocónicos perforados para filtrar garum y otros usos industriales en la Bahía de Cádiz". Romula 5: 167-218.

Bonsor, G. (1897): "Notas arqueológicas de Carmona". Revista de Archivos, Bibliotecas y Museos I: 231-233.

Carmona Bohórquez, D. (1635-1639): Historia sacra del insigne origen y raro aparecimiento de la antiquísima imagen de Nuestra Señora de Regla y sus admirables y maravillosas obras. BNE. Sede de Recoletos. MSS/1177. Inédito.

Cebrián Fernández, R. y Herrero Fernández, T. (2008): "Las aras de la necrópolis de Boatella (Valencia)". Archivo de Prehistoria Levantina XXVII: 303-317.
Cervera y Jimenez-Alfaro, F. (1923): Excavaciones en extramuros de Cádiz. Memoria acerca de los trabajos y resultados obtenidos en dichas excavaciones. Madrid, Junta Superior de Excavaciones y Antigüedades.

Dunand, F. (1997): "La consultation oraculaire en Egypt tardive: 1'oracle de Bès à Abydos". Travaux du centre de recherche sur le Proche-Orient et la Grèce antiques 15: 65-84.

Fernández-Chicarro y de Dios, C. (1962): "Informe arqueológico de los hallazgos más sobresalientes habidos en Andalucía durante el bienio 1959-1961", Actas del VII Congreso Arqueológico Nacional: 6575. Barcelona (1960), Zaragoza, Secretaría General de los Congresos Arqueológicos Nacionales.

Gamer Wallert, I. (1978): Ägyptische und ägyptisierende Funde von der iberischen Halbinsel. Wiesbaden, Dr. Ludwig Reichert.

Garbati, G. (2009): "L'immagine di Bes in Sardegna: appunti su un indicatore morfologico", en C. Bonnet, V. Pirenne-Delforge y D. Praet (eds.), Les religions orientales dans le monde grec et romain: cent ans après Cumont (1906-2006). Bilan historique et historiographique: 293-308. Roma (2006), Bruselas, Belgisch Historisch Instituut te Rome.

García Cano, J. M. (1997): La necrópolis ibérica de Coimbra del Barranco Ancho (Jumilla, Murcia) I. Las excavaciones y estudio analítico de los materiales. Murcia, Universidad de Murcia.

García Martínez, M. A. (2001): Documentos prerromanos de tipo egipcio de la vertiente atlántica hispano-mauritana. Vols. 1 y 2 . Montpellier, Université Paul-Valéry.

García Vargas, E. (1998): La producción de ánforas en la bahía de Cádiz en época romana: (siglos II a.C.IV d.C.). Écija, Gráficas Sol.

Gestoso Morote, D. y López Rodríguez, J. I. (2009): La necrópolis altoimperial de "Carteia" y el mundo funerario romano. Málaga, CEPSA.

Gómez Lucas, D. (2002): "Introducción al dios Bes: de Oriente a Occidente", en E. Ferrer Albelda (ed.), Ex Oriente Lux: Las religiones orientales antiguas en la Península Ibérica: 87-121. Sevilla, Fundación El Monte y Universidad de Sevilla.

González Fernández, J. (1982): Inscripciones romanas de la provincia de Cádiz. Cádiz, Diputación de Cádiz.

González Prats, A. (1999-2000): "La Fonteta. La colonia fenicia de la desembocadura del río Segura". Sapanu III-IV. Publicado electrónicamente en http:// www.labherm.filol.csic.es 
Hermary, A. (1986): "Bes (Cypri et in Phoenicia)", en Lexicon Iconographicum Mythologiae Classicae: vol. III, 1, 108-112. Zürich, Artemis Verlag.

Jiménez Cisneros, M. J. (1971): Historia de Cádiz en la Antigüedad. Cádiz, Instituto de Estudios Gaditanos.

Jiménez Flores, A. M. (2004): “Aegyptiaca: datos sobre la espiritualidad en la necrópolis de Gadir". Spal 13: 139-154. Doi http://dx.doi.org/10.12795/ spal.2004.i13.05

Kákosy, L. (2002): “À propos des statues guérriseurs et d'une statue de Bès au musée du Louvre", en Y. Koenig (dir.), La magie en Égypte: à la recherche d'une définition: 273-284. París. Éditions du Musée du Louvre.

Kodandaramaiah, U. (2009): "Eyespot Evolution: Phylogenetic Insights from Junonia and Related Butterfly Genera (Nymphalidae: Junoniini)". Evolution \& Development 11, 5: 489-497. http:// vanasiri.in/uploads/Junonia_eyespot_patterns.pdf [18/08/2012] doi: http://dx.doi.org/10.1111/j.1525142X.2009.00357.x.

Lancel, S. (1994): Cartago. Barcelona, Crítica.

López Flores, I. y Tinoco Muñoz, J. (2007): "Resultados antropológicos de campo de la necrópolis romana hallada en c/ Bellidos, 18 (Écija, Sevilla)". Caesaraugusta 78: 609-630.

Lyytinen, A.; Brakefield, P. M. y Mappes, J. (2003): "Significance of Butterfly Eyespots as an Anti-predator Device in Ground-based and Aerial Attacks". Oikos 100: 373-379. http://onlinelibrary.wiley.com/ doi/10.1034/j.1600-0706.2003.11935.x/abstract [25/08/2012] doi: http://dx.doi.org/10.1034/j.16000706.2003.11935.x.

Madrazo, P. (1884): España, sus monumentos y artes. Su naturaleza e historia: Sevilla y Cádiz. Barcelona, Establecimiento Tipográfico-Editorial de Daniel Cortezo y $\mathrm{C}^{\mathrm{a}}$.

Maier Allende, J. (1999): Jorge Bonsor (1855-1930). Un académico correspondiente de la Real Academia de la Historia y la Arqueología Española. Madrid, Real Academia de la Historia.

Marco Simón, F. (2007): “Ex Oriente Magia: adaptación y cambios rituales en el mundo helenístico-romano", en J. J. Justel et al. (eds.), Las aguas primigenias. El Próximo Oriente Antiguo como fuente de civilización: 17-40: Zaragoza, Instituto de Estudios Islámicos y del Oriente Próximo.

Martínez Munilla, C. (1949): "Vaso de terra sigillata hallado en las inmediaciones del Santuario de Nuestra Señora de Regla (Chipiona)". Archivo Español de Arqueología 22 (76): 237-240.
Mata Almonte, E. (1999): "La historia descubierta en Santo Domingo $\mathrm{n}^{\circ}$ 9". Revista de Historia de El Puerto de Santa María 22: 11-34.

McClellan, M.C.; Reinoso del Río, M.C., Gutiérrez López, J.M. y Mackinnon, M. (2010): "Una villa romana en la Base Naval", en J.M. Gutiérrez López y M.C. Reinoso (eds.), De la Prehistoria a la Rábita y la Villa. Arqueología de Rota y la Bahía de Cádiz: 109-148. Chiclana de la Frontera, Fundación Alcalde Zoilo Ruiz-Mateos.

Medrano Marqués, M. y Díaz Sanz, M.A. (2000): “El alfar romano, villa y necrópolis de Villarroya de la Sierra (Zaragoza)". Saldvie 1: 273-282.

Molina Fajardo, F.; Ruiz Fernández, A. y Huertas Jiménez, C. (1982): Almuñécar en la antigüedad: la necrópolis fenicio-púnica de Puente de Noy. Granada, Caja de Ahorros de Granada.

Molina Fajardo, F. y Padró i Parcerisa, J. (1983): “Una sepultura con amuletos de tipo egipcio de Puente de Noy (Almuñécar, Granada)", en F. Molina (dir.), Almuñécar: Arqueología e Historia. Vol. 1: 107-122. Granada, Caja de Ahorros de Granada.

Niveau de Villedary y Mariñas, A.M. y Blanco Jiménez, F.J. (2007): “Continuidad púnica en la Gades republicana. La producción vascular del horno de la calle Troilo". Spal 16: 195-224. Doi: http://dx.doi. org/10.12795/spal.2007.i16.10

Pannuti, U. (1983): Museo Archeologico Nazionale di Napoli. Catalogo della collezione glittica, 1 (Cataloghi dei musei e gallerie d'Italia). Roma, Librería dello Stato.

Perdigones, L.; Troya, A. y Muñoz, A. (1987): "Excavaciones de urgencia en un solar de la Avenida Andalucía (Cádiz) en 1985". Anuario Arqueológico de Andalucía 1985: vol. III, 71-73. Sevilla, Junta de Andalucía.

Ponsich, M. (1991): Implantation rurale Antique sur le Bas Guadalquivir. Madrid, Casa de Velázquez.

Rey Seara, E. (1989): "Notas sobre la fascinación en la Antigüedad". Gallaecia 11: 229-238.

Riesco García, F. (1987): Carta Arqueológica de la Desembocadura del Guadalquivir: Zona Sur. Tesina de Licenciatura, Universidad de Sevilla. Inédita.

Rodríguez Temiño, I.; Jiménez Hernández, A., González Acuña, D. y Ruiz Cecilia, J. I. (2012): “Avance de las nuevas investigaciones en la Necrópolis Romana de Carmona". Spal 21: 127-151. Doi: http:// dx.doi.org/10.12795/spal.2012.i21.08

Romano, J. F. (1989): The Bes-Image in Pharaonic Egypt. Tesis doctoral, Nueva York. Inédita.

Sáez Romero, A. M. y Díaz Rodríguez, J. J. (2010): "La otra necrópolis de Gadir/Gades. Enterramientos 
asociados a talleres alfareros en su hinterland insular", en A. M. Niveau y V. Gómez (coords.), Las necrópolis de Cádiz. Apuntes de arqueología gaditana en homenaje a J. F. Sibón Olano: 251-337. Cádiz, Servicio de Publicaciones de la Universidad de Cádiz.

Sillières, P. (1997): Baelo Claudia: una ciudad romana en la Bética. Madrid, Casa de Velázquez.

Tejera Gaspar, A. (1979): Las tumbas fenicias y púnicas del Mediterráneo Occidental (estudio tipológico). Sevilla, Universidad de Sevilla.

Toro Rueda, M. I. (2006): Nacimiento y protección en el Mediterráneo: el caso de Bes. Madrid, Universidad Complutense de Madrid.

Tran Tam Tinh, V. (1986): "Bes", en Lexicon Iconographicum Mythologiae Classicae. vol. III, 1: 98-108. Zürich, Artemis Verlag.
Vaquerizo Gil, D. (2002): "Espacio y usos funerarios en Corduba", en D. Vaquerizo Gil (ed.), Espacio y usos funerarios en el Occidente romano: actas del Congreso Internacional: vol. 2, 141-201. Córdoba (2001), Córdoba, Universidad de Córdoba.

Vaquerizo Gil, D. (2012): "De nuevo, sobre el sustrato púnico en el mundo funerario de la Bética. Reflexiones, desde la incertidumbre". Spal 21: 183-194. Doi: http://dx.doi.org/10.12795/spal.2012.i21.09

Velázquez Brieva, F. (2007): El dios Bes: de Egipto a Ibiza. Ibiza, Museo Arqueológico de Ibiza.

Vercoutter, J. (1945): Les objets égyptiens et égyptisants du mobilier funéraire Carthaginois. Paris, Librairie Orientaliste Paul Geuthner.

Vives, J. (1942): Inscripciones cristianas de la España romana y visigoda. Barcelona, CSIC. 